\title{
Geochemistry and petrology of gold-bearing hydrothermal alteration zones on Qilanngaarsuit, southern West Greenland
}

\author{
Martin Koppelberg, Annika Dziggel, Denis Martin Schlatter, Jochen Kolb and Franz Michael Meyer
}

During field work in 2008, the Geological Survey of Denmark and Greenland investigated the gold potential of hydrothermal vein systems in the Nuuk region of the Archaean North Atlantic craton. A new gold occurrence was discovered on the island of Qilanngaarsuit, $35 \mathrm{~km}$ south of Nuuk. Two cross sections through hydrothermal alteration zones, that locally contain up to $672 \mathrm{ppb} \mathrm{Au}$, were mapped and sampled in detail. In this study, we present petrological and geochemical data in order to constrain the conditions for ore formation and transport of elements during fluid-rock interaction.

\section{Geological setting}

Qilanngaarsuit in southern West Greenland (Fig. 1) is situated in the Godthåbsfjord gold province, a $c .20 \mathrm{~km}$ by $150 \mathrm{~km}$ wide, NE-trending sector along the Ivinnguit fault system. Several gold occurrences such as Storø, Qussuk, Bjørneøen and SW Isua have been described from this sector (Garde et al. 2012; Scherstén et al. 2012; Kolb et al. 2013). The Ivinnguit fault, situated north of the island, is a deep-crustal shear zone, which formed during terrane amalgamation and it represents the border between the Færingehavn and Akia terranes (Nutman \& Friend 2007). Qilanngaarsuit island is dominated by Eoarchaean tonalite-trondhjemite-granodiorite (TTG) gneisses of the Færingehavn terrane, which are overlain by amphibolites and aluminous cordierite-orthoamphibole gneisses that originated from c. 2840 Ma old protoliths (Nutman \& Friend 2007). Four deformation events can be distinguished, involving north-vergent thrusting, isoclinal folding and the formation of late, upright, open to tight folds (e.g. Kolb et al. 2013). The gold-bearing quartz veins are hosted by amphibolites in the central part of the island and surrounded by approx. $8 \mathrm{~m}$ wide hydrothermal alteration zones. The foliation-parallel, $c$. $10-20 \mathrm{~cm}$ wide, quartz veins can be followed over several hundred metres along strike. Structural data indicate that they formed in response to flexural, slip folding during the late-tectonic evolution of the region (Kolb et al. 2013). One sample from a hydrothermal alteration zone surrounding the veins contains up to 672 ppb Au and several other vein and alteration zone samples have elevated Au contents (> 20 ppb Au; Kolb et al. 2009).

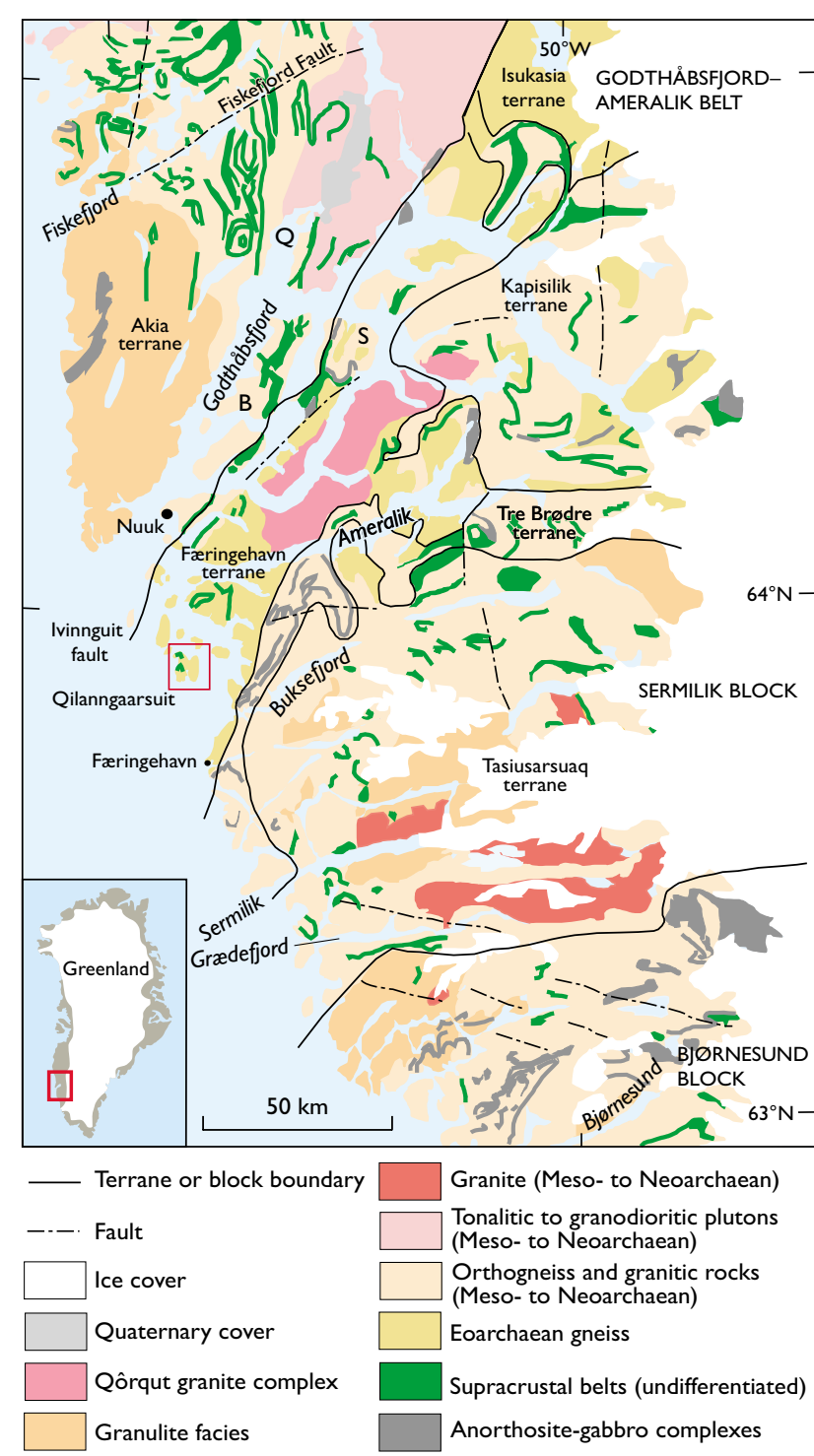

Fig. 1. Geological map of the Nuuk region (modified from Allaart 1984). B: Bjørneøen, Q: Qussuk, S: Storø. 


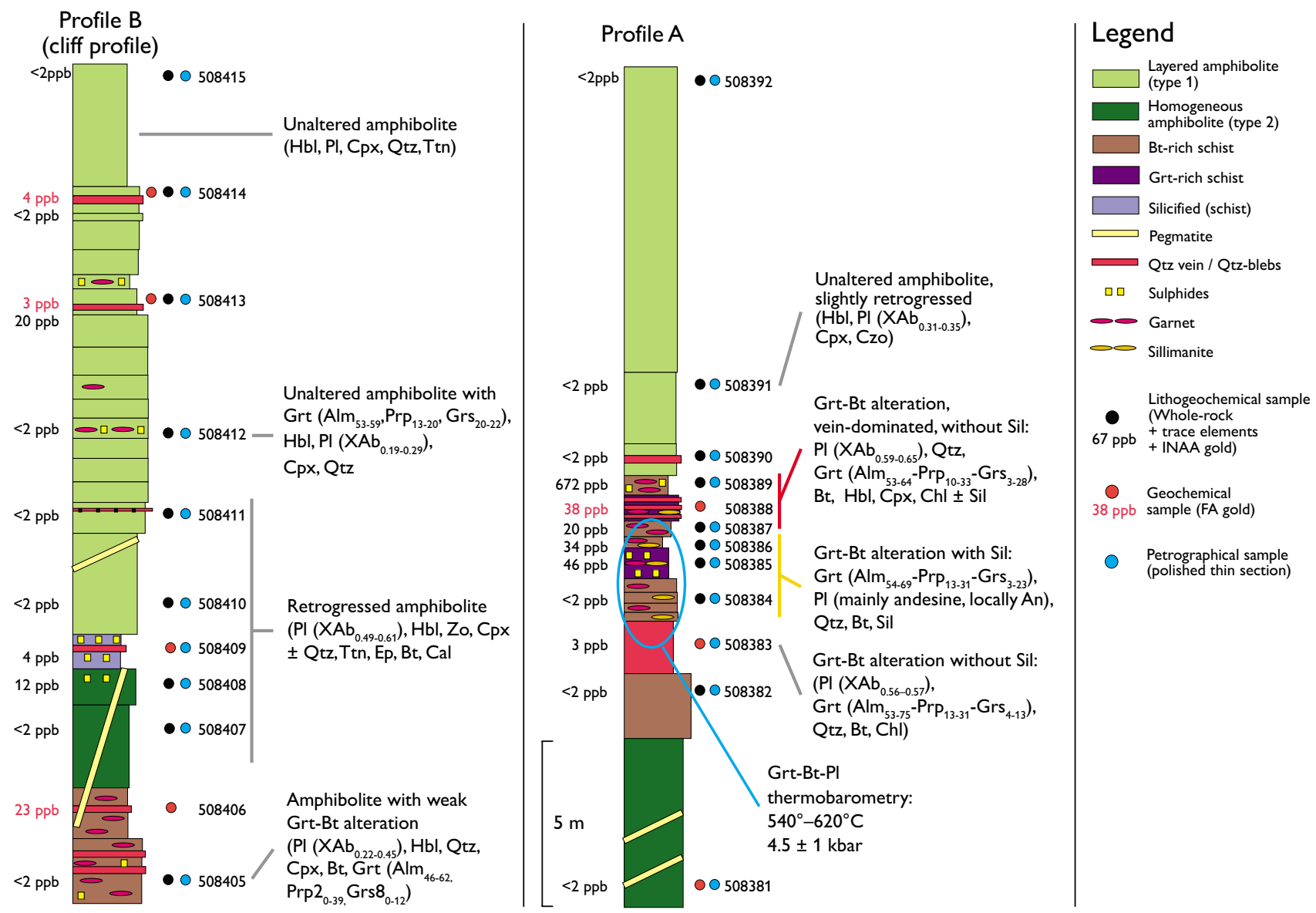

Fig. 2. Lithological logs of profiles A and B (modified from Schlatter 2009).

\section{Petrology and geochemistry}

Two profiles from the unaltered wall rocks through the hydrothermal alteration zones were investigated (Fig. 2). Two types of amphibolite can be distinguished: homogeneous amphibolite in the footwall and compositionally layered amphibolite in the hanging wall of the hydrothermal vein system. Their protoliths were low-K tholeiites depleted in light rare-earth elements (LREE), geochemically similar to other amphibolites in the Buksefjord region (Chadwick 1981). Generally, the amphibolites are fine- to medium-grained and consist of hornblende ( $40 \mathrm{vol} . \%$ ), plagioclase (30 vol.\%), clinopyroxene (20 vol.\%) and clinozoisite/zoisite/epidote (10 vol.\%). Metamorphic garnet is locally present in the layered amphibolite. Retrogression is indicated by the transformation of plagioclase to a fine-grained assemblage of zoisite and quartz, and by the replacement of amphibolite and clinopyroxene by epidote and clinozoisite.

Within the alteration zone, the amphibolite-facies mineral assemblages are replaced by a high temperature alteration assemblage of garnet, quartz, plagioclase, biotite, and sillimanite (Figs 2, 3). In contact with the veins, the hy- drothermal alteration zone consists of up to 50 vol.\% garnet, 15 vol.\% plagioclase, 15 vol.\% quartz, 10 vol.\% biotite and 10 vol.\% sillimanite (Fig. 2). Relict amphibole facies minerals such as hornblende and clinopyroxene are locally preserved, indicating that these minerals formed during regional metamorphism prior to the mineralisation. Ore minerals make up $\leq 1 \mathrm{vol}$. \% of the rocks; they include pyrite, pyrrhotite and chalcopyrite. Mass-balance calculations based on whole-rock, major- and trace- element data (Kolb et al. 2009; Koppelberg 2011) and using the method of Gresens (1967) indicate that the ore fluid was enriched in $\mathrm{Si}, \mathrm{K}, \mathrm{LREE}, \mathrm{Au}$, $\mathrm{Cr}, \mathrm{Cu}, \mathrm{Zn}, \mathrm{Mo}$ and As (Fig. 4). In Si-rich, vein-dominated samples, the hydrothermal overprint was associated with a volume increase of $14-62 \%$. In contrast, the sillimanitebearing samples record a significant volume loss of $15-50 \%$, and are depleted in $\mathrm{Si} \mathrm{(Fig.} \mathrm{4).} \mathrm{This} \mathrm{suggests} \mathrm{that} \mathrm{at} \mathrm{least} \mathrm{some}$ of the $\mathrm{Si}$ in the quartz veins was leached from the surrounding wall rocks.

Garnet in the alteration zones is rich in almandine (Koppelberg 2011). Most grains are essentially unzoned and have 


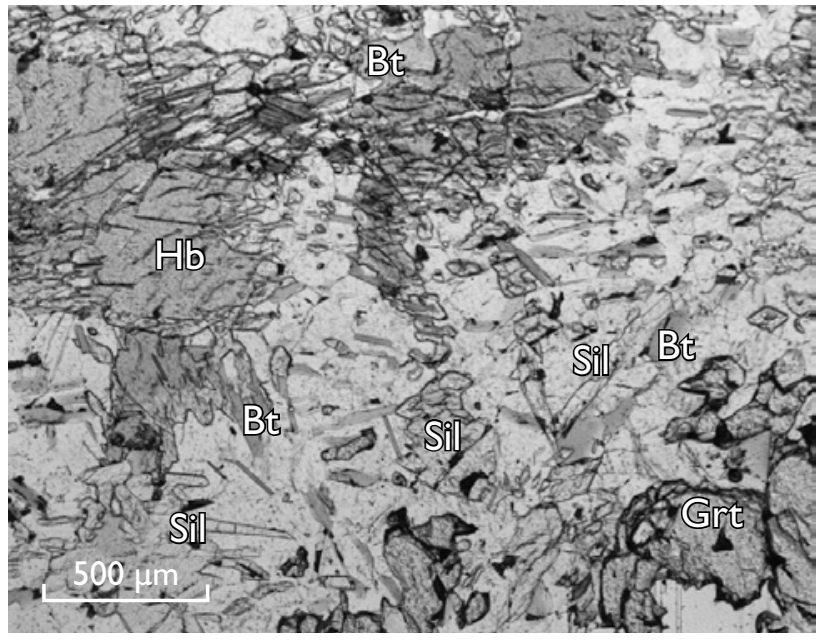

Fig. 3. Photomicrograph illustrating the replacement of the regional metamorphic amphibolite facies mineral assemblages by hydrothermal garnet, biotite and sillimanite in sample GGU 508405.

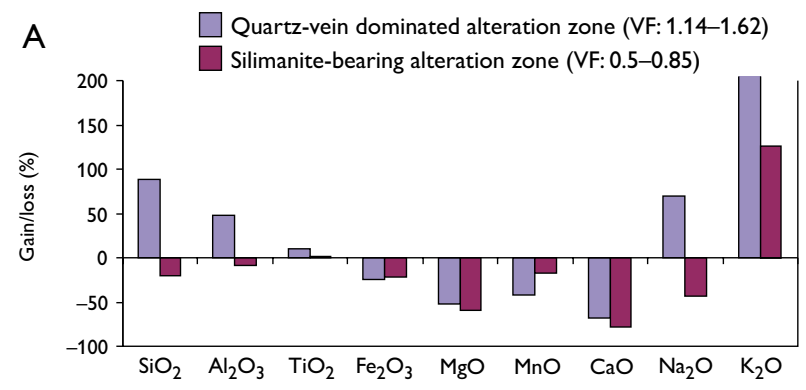

B
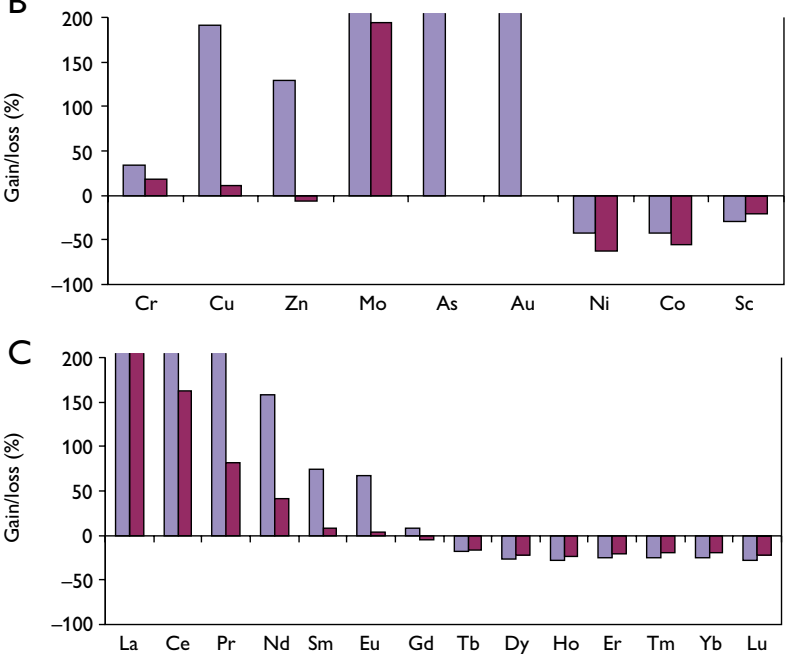

Fig. 4. Results of mass-balance calculations for quartz-vein dominated and sillimanite-bearing alteration zones. VF: volume factor - the change of volume of altered rock relative to unaltered rock. A: major elements, B: trace elements, C: rare-earth elements (REE).

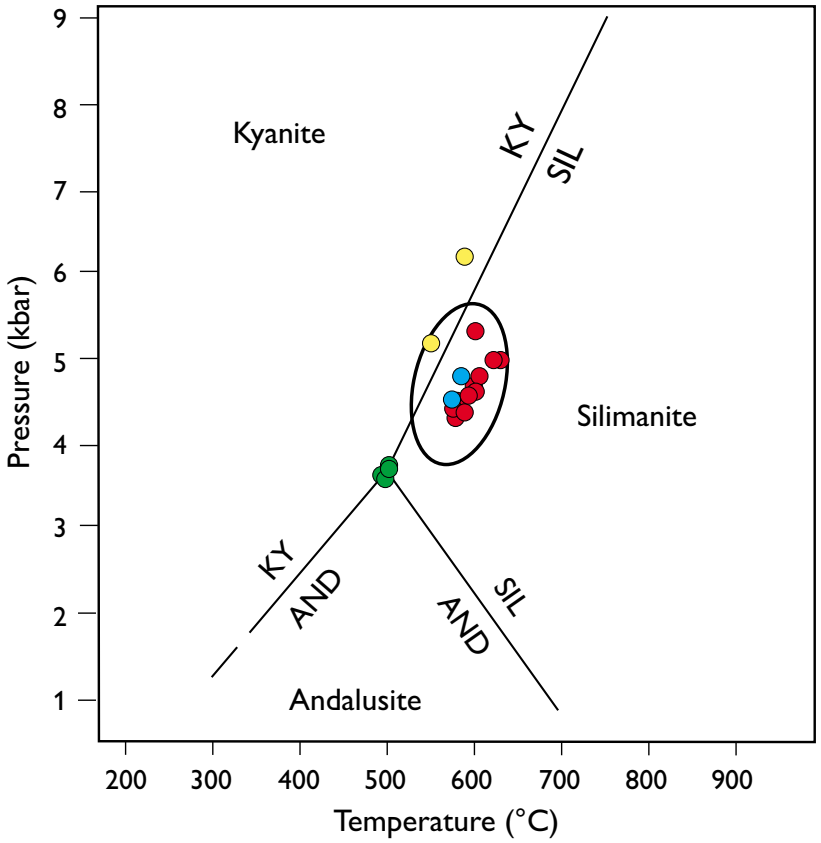

Fig 5. Thermobarometry results (see main text). The Al2SiO5 diagram is from Holdaway \& Mukhopadhyay (1993). Red: sample GGU 508384, green: 508385, blue: 508386, yellow: 508405. The Al2SiO5 triple point is at $500^{\circ} \mathrm{C}$ and $3.75 \mathrm{kbar}$.

a composition of $\mathrm{Alm}_{53-69}, \operatorname{Prp}_{21-31}$, Grs $\mathrm{Gr}_{3-12}$, depending on bulk composition. In some of the larger grains, the rims have slightly higher Fe concentrations ( $\operatorname{Alm}_{62-72}, \operatorname{Prp}_{20-25}$, $\left.\mathrm{Grs}_{3-10}\right)$. Metamorphic garnet in the unaltered wall rocks is unzoned and enriched in grossular $\left(\mathrm{Alm}_{53-59}, \operatorname{Prp}_{13-20}\right.$, Grs $\left._{17-21}\right)$. Both types of garnet have very low REE contents $(<2 \mathrm{ppm})$, and are depleted in LREE. Biotite in the alteration zone has $\mathrm{Al}^{\mathrm{IV}}$ contents between 2.4 and 2.65 atoms per formula unit and $\mathrm{Mg} /(\mathrm{Fe}+\mathrm{Mg})$ ratios between 0.25 and 0.45 . The composition of plagioclase from the amphibolites varies from andesine to anorthite; most grains can be classified as labradorite and bytownite. Plagioclase in the hydrothermal alteration zone is depleted in $\mathrm{Ca}$ and is mostly andesine.

In order to achieve reliable pressure-temperature $(P-T)$ estimates, only mineral cores of neighbouring minerals were used for geothermobarometry. Due to the presence of retrograde reaction rims in some of the garnet grains, it was assumed that the mineral cores reflect the equilibrium mineral composition and were not altered by retrograde processes. $P-T$ estimates on the alteration assemblage using the garnetbiotite-plagioclase-quartz geothermobarometer of Wu et al. (2004) give conditions of $c .540-620^{\circ} \mathrm{C}$ and $4.5 \pm 1 \mathrm{kbar}$ (Fig. 5). $P-T$ pseudosection models using the computer program PeRpLeX developed by Connolly (1990) confirm these conditions (Koppelberg 2011). 


\section{Discussion and conclusion}

The majority of the world's gold deposits formed in the Archaean $(c .2 .7 \mathrm{Ga})$ as a result of crust-forming processes during collision events of converging continental plates (Groves et al. 2005). These epigenetic deposits are called orogenic gold deposits, and occur in metamorphic terranes that mainly show greenschist facies metamorphism (Groves et al. 1998). Other orogenic deposits are known to have formed at amphibolite-facies metamorphic grades, and these are termed hypozonal deposits (Groves et al. 1998). The replacement of regional, metamorphic, amphibolite-facies mineral assemblages by hydothermal minerals surrounding the goldbearing quartz veins as well as the late timing of quartz-vein formation by ductile, flexural slip folding (Kolb et al. 2009), indicate that the gold mineralisation and associated hydrothermal alteration formed late in the metamorphic evolution on Qilanngaarsuit. The low-pressure amphibolite-facies metamorphism in the surrounding amphibolites has been dated to $c$. $2715 \mathrm{Ma}$ (Nutman \& Friend 2007), while the mineralisation probably occurred between 2660 and $2600 \mathrm{Ma}$ (Kolb et al. 2013). The Qilanngaarsuit mineralisation is, therefore, interpreted to represent a new example of hypozonal orogenic gold mineralisation in the Godthåbsfjord gold province. The origin of other gold prospects (Storø, Qussuk) is still a matter of debate, and both metamorphosed epithermal and orogenic models have been proposed (Garde et al. 2012; Scherstén et al. 2012; Kolb et al. 2013). The alteration systematics, timing and conditions of the gold mineralisation on Qilanngaarsuit are, however, similar to those of other gold occurrences, in particular Storø, in the Godthåbsfjord gold province. The deposits are spatially closely associated with a major terrane boundary, the Ivinnguit fault, suggesting that this shear zone may have acted as a major pathway for the gold-bearing fluids between $c$. 2660-2600 Ma.

\section{Acknowledgements}

The Professor Dr. Karl-Heinrich Heitfeld-Stiftung is thanked for financial support. The work benefited from valuable comments and discussions with Susan Giffin and Nicolas Stoltz.

\section{References}

Allaart, J.H. 1982: Geological maps of Greenland 1:500 000. Map sheet no. 2, Frederikshåb Isblink - Søndre Strømfjord. Copenhagen: Geological Survey of Denmark and Greenland.
Chadwick, B. 1981: Field relations, petrography and geochemistry of Archaean amphibolite dykes and Malene supracrustal amphibolites, northwest Buksefjorden, southern West Greenland. Precambrian Research 14, 221-259.

Connolly J.A.D. 1990: Multivariable phase diagrams: an algorithm based on generalised thermodynamics. American Journal of Science 290, 666-718.

Garde, A.A., Whitehouse, M. \& Christensen, R. 2012: Mesoarchean epithermal gold mineralisation preserved at upper amphibolite-facies grade, Qussuk, southern West Greenland. Economic Geology 107, 881-908.

Gresens, P.L. 1967: Composition-volume relationships of metasomatism. Chemical Geology 2, 47-65.

Groves, D.I., Goldfarb, R.J., Gebre-Mariam, M., Hagemann, S.G. \& Robert, F. 1998: Orogenic gold deposits: a proposed classification in the context of their crustal distribution and relationship to other gold deposit types. Ore Geology Reviews 13, 7-27.

Groves, D.I., Condie, K.C., Goldfarb, R.J., Hronsky, J.M.A. \& Vielreicher, R.M. 2005: Secular changes in global tectonic processes and their influence on the temporal distribution of gold-bearing mineral deposits. Economic Geology 100, 203-224.

Holdaway, M.J. \& Mukhopadhyay, B. 1993: A re-evaluation of the stability relations of andalusite: thermochemical data and phase diagram for the aluminum silicates. American Mineralogist 78, 298-315.

Kolb, J., Stensgaard, B.M., Schlatter, D.M. \& Dziggel, A. 2009: Controls of hydrothermal quartz vein mineralization and wall-rock alteration between Ameralik and Sermilik, southern West Greenland. Danmarks og Grønlands Geologiske Undersøgelse Rapport 2009/25, 76 pp.

Kolb, J., Dziggel, A. \& Schlatter, D.M. 2013: Gold occurrences of the Archean North Atlantic Craton, southwestern Greenland: a comprehensive genetic model. Ore Geology Reviews 54, 29-58.

Koppelberg, M. 2011: Geochemische und petrologische Charakterisierung einer goldführenden hydrothermalen Alterationszone auf der Insel Qilanngaarsuit, SW Grönland, 70 pp. Unpublished Diploma thesis, Institut of Mineralogy and Economic Geology, RWTH Aachen University.

Nutman, A.P. \& Friend, C.R.L. 2007: Adjacent terranes with c. 2715 and 2650 Ma high-pressure metamorphic assemblages in the Nuuk region of the North Atlantic Craton, southern West Greenland: complexities of Neoarchaean collisional orogeny. Precambrian Research 155, 159-203.

Scherstén, A., Szilas, K., Creaser, R.A., Næraa, T., van Gool, J.A.M. \& Østergaard, C. 2012: Re-Os and U-Pb constraints on gold mineralisation events in the Meso- to Neoarchaean Storø greenstone belt, Storø, southern West Greenland. Precambrian Research 200-203, 149-162.

Schlatter, D.M. 2009: Petrographic and lithogeochemical surface data from the new gold occurrence on Qilanngaarsuit Island, southern West Greenland. In: Kolb, J \& Kokfelt, T.: Annual workshop on the geology of southern West Greenland realted to field work: abstract volume 1, GEUS Rapport 2009/94, 18-21.

Wu, C.-M., Zhang, J. \& Ren, L.-D. 2004: Empirical garnet-biotite-plagioclase-quartz (GBPQ) geobarometry in medium- to high-grade metapelites. Journal of Petrology 45, 1907-1921.

\footnotetext{
Authors' addresses

M.K., A.D., F.M.M., Institute of Mineralogy and Economic Geology, RWTH Aachen University, Wüllnerstraße 2, 52056 Aachen, Germany;

E-mail:koppelberg@iml.rwth-aachen.de

D.M.S., Helvetica Exploration Services GmbH, Carl Spitteler Strasse 100, CH-8053 Zürich, Switzerland.

J.K., Geological Survey of Denmark and Greenland, Øster Voldgade 10, DK-1350 Copenhagen K, Denmark.
} 